\title{
Identification of Threats to the Soil and Water Environment on the Example of an Inactive Landfill Site
}

\author{
Agnieszka Pusz ${ }^{1 *}$, Magdalena Wiśniewska', Dominik Rogalski', Grzegorz Grzyb \\ 1 Warsaw University of Technology, Faculty of Building Services, Hydro and Environmental Engineering, \\ Nowowiejska 20, 00-653 Warsaw, Poland \\ *Corresponding author's e-mail: agnieszka.pusz@pw.edu.pl
}

\begin{abstract}
Pollution migration is the main problem of the landfills that have been located, installed and operated without meeting basic environmental protection requirements. Undertaking effective reclamation treatments is conditioned by a good recognition of the object and its close and distant surroundings. The purpose of the work was to determine the potential hazard to the soil and water environment, based on selected factors, in the vicinity of a closed waste landfill at Głębocka Street in Warsaw. In the soil samples taken at the site from various depths, high concentrations of chlorides, EC, ammonium nitrogen and phosphates were found. Furthermore, the high ammonium nitrogen content correlated with the scent of ammonia, and the content of phosphates with the scent of organic compounds. These pollutants testify to the progressive decomposition of substances occurring in the mass of littering waste, which may pose a serious threat to groundwater. The landfill is also a potential geotechnical hazard because it is a dynamically changing object that can change stability, create caverns and landslides.
\end{abstract}

Keywords: landfill, soil and water environment, distribution of pollutants, available phosphorus, ammonium nitrogen, chlorides, EC, migration of pollutants

\section{INTRODUCTION}

Municipal waste and the waste from the economic sector deposited in landfills are a potential centre of environmental pollution. In the absence of proper sealing of the storage site, leached contaminants may cause degradation of the soil and water environment. Leachates constitute one of the sources causing the spread of pollutants in the soil and water environment. They arise due to the biochemical decomposition of organic compounds and through the leaching by rainwater and surface runoffs of soluble mineral and organic fractions that are contained in the stored waste [Tabor 2008]. The composition and amount of leachate generated depend on many factors, including the type of waste, the degree of their fragmentation, thickness and degree of waste compaction, age of the deposited waste, storage technology, the nature of biochemical and physicochemical changes, humidity and re- tention capacity of the stored waste, the amount and intensity of atmospheric precipitation, evaporation rate, protection method (sealing of the surface of the landfill), the hydrogeological conditions of the substrate, as well as the type of vegetation growing on the land after reclamation [Tabor 2008; Marcinkowski 2009]. The range of pollutants spread in groundwater is affected, among others by the ground level of the landfill, groundwater flow rate, hydraulic loss of these waters, filtration rate of aquifers, concentration of pollutants, properties and amount of leachate and the sorption capacity of the ground [Tabor 2008]. Soil is the element that is relatively the most resistant to the impact of landfills. Most often, the soil contamination occurs in a close proximity to the object and mainly in the subsurface layers [Siuta 1995; Koda, Koper 2009]; however, as far as permeable works are concerned, the migration of pollutants may occur, which may pose a potential threat to the groundwater 
[Grygolczuk-Patersons, Wiater 2012]. The problem particularly concerns the landfills that have not been designed in the right way. Undertaking effective recultivation measures [The Waste Act 2012] is conditioned by a proper diagnosis of the object and its immediate and further environment [Mizera 2007]. Conducting a cursory reclamation does not lead to full protection against the negative effects of impacts on the ground and water environment. Often, there are conditions conducive to the migration of toxic mineral substances and organic compounds that persist for many years [Koda, Koper 2009]. The purpose of the work was to determine the potential hazard to the soil and water environment, based on selected properties, in the vicinity of a closed waste landfill at Głębocka Street in Warsaw.

\section{RESEARCH OBJECT}

The research site was a landfill site located at Głębocka Street in Warsaw, in the municipality of Targówek on the western edge of the Forest Park "Bródno". It covers an area of about 4 ha, and the difference in altitude at the highest point in relation to the surrounding area is $12.5 \mathrm{~m}$. The scarp from the north-east is steep, whereas in the southern part it is mild (Figure 1). In the eastern part of the landfill, there are wetlands that may indicate leachate and abnormal ground-water relations (Figure 2). The lack of documentation regarding the landfill, the amount and type of waste deposited and its history, causes problems related to its potential impact on the ground and water environment. The landfill mainly deposited the organic waste from Zakłady Farmaceutyczne "Polfa" and Zakłady Mięsne "Żerań".

The vegetation around the object under examination is mainly composed of Betula L. and Pinus sylvestris $L$. species. In the eastern part, wetlands are present, the following species can be found: Alnus glutinosa, Betula pubescens, Sambucus nigra and Prunus padus. The crown of the landfill is mainly covered with grasses, single trees and shrubs.

\section{MATERIALS AND METHODS}

Twenty wells were drilled to assess the land degradation. From each well, two samples were taken from two depths $0-0.3 \mathrm{~m}$ and $0.8-1.0 \mathrm{~m}$ (taking into account the differences in the height of the terrain) using a soil drill. Individual depths were marked with the letters "a" for $0-0.3 \mathrm{~m}$ and "b" for $0.8-1.0 \mathrm{~m}$. The first area of research included the samples taken along the forest road (1), while the second area of research involved the samples taken on the scarp of storage sites (2). In each area, 10 wells from I to X were located (Figure 3, 4). The boreholes for both areas are placed at equal distance, every $15 \mathrm{~m}$.

The collected samples were subjected to further preparations for the selected analyzes, according to PN-ISO 11464 standard. The chemical analysis was carried out in air-dry samples of known hygroscopic humidity. The tests were performed according to the following methodologies: type of smell, particle size distribution. sieve and Casagrande in modif. Prószyński, color, $\mathrm{pH}$ in $1 \mathrm{M} \mathrm{KCl}$ according to PN-ISO 10390:

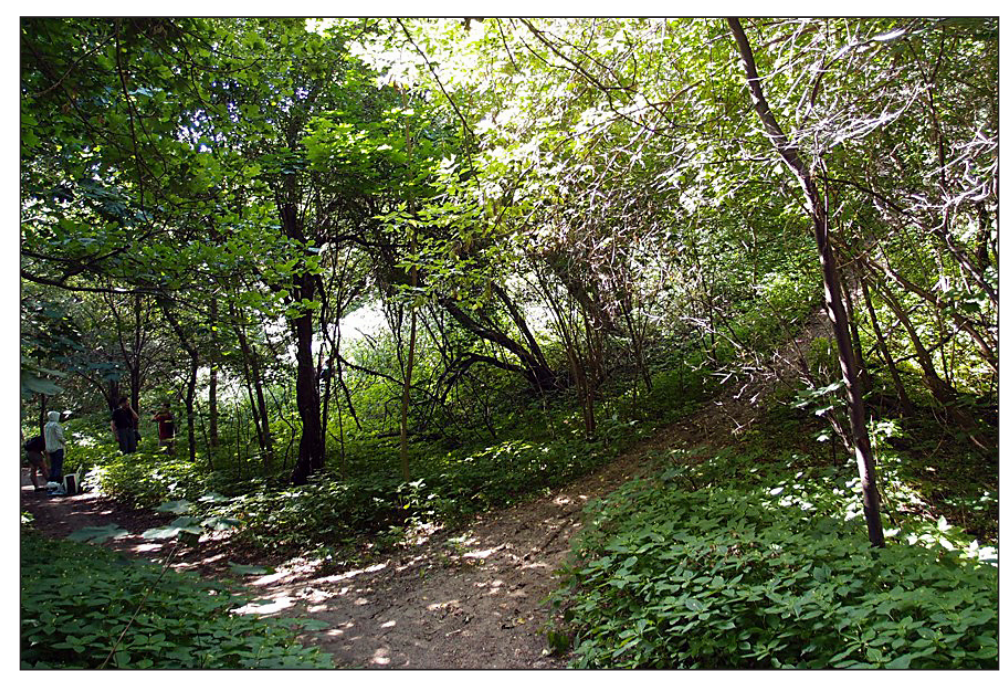

Figure 1. Landfill - view of the scarp from the east 


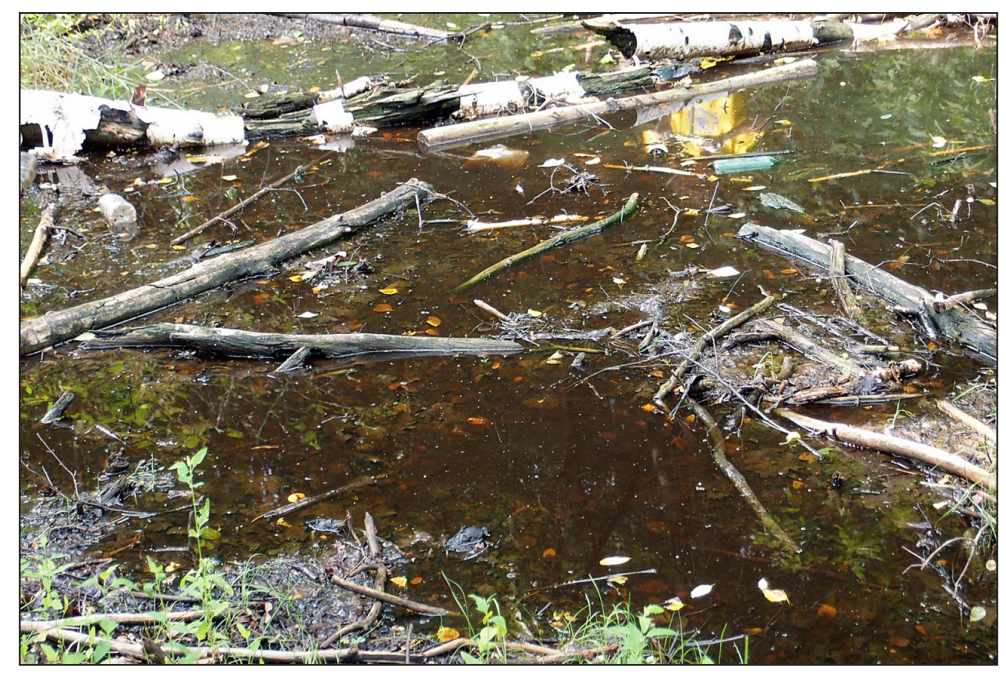

Figure 2. Leachates at the eastern base of the landfill site

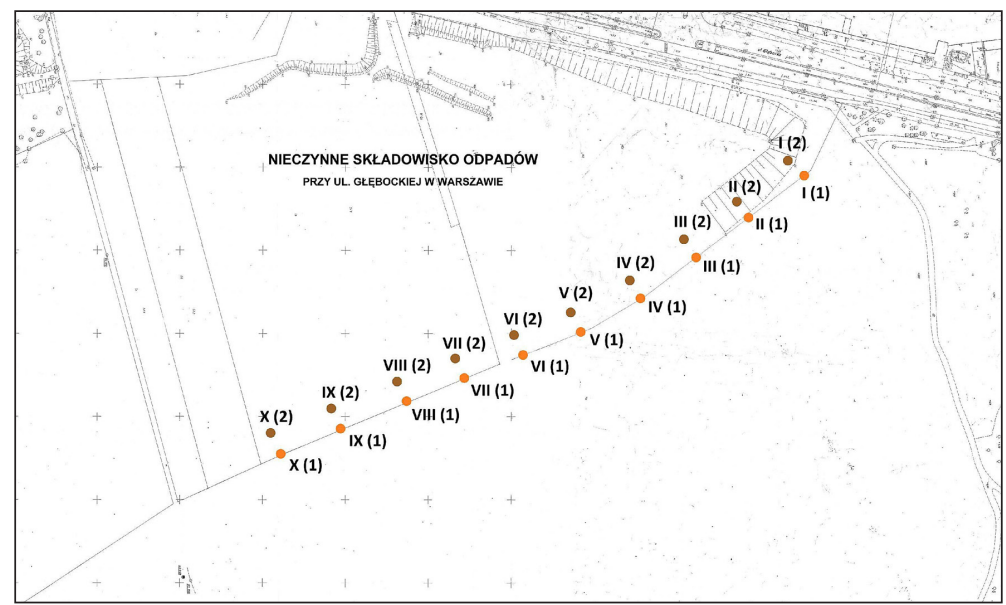

Figure 3. Location of wells along the forest road (1) and on the scarp of the landfill (2)

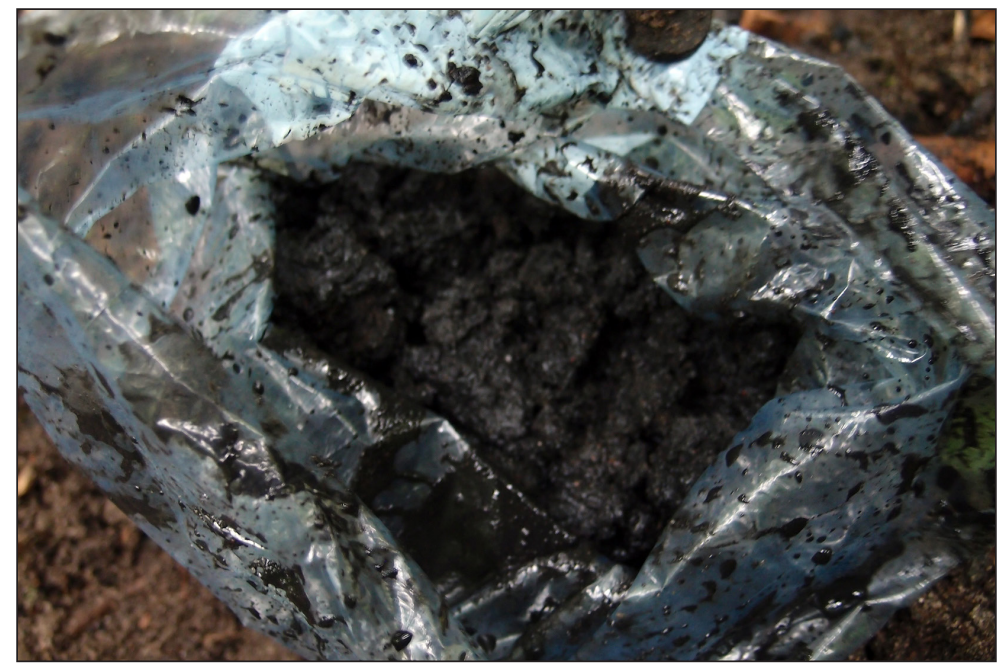

Figure 4. Soil sample from point VI (2) from 0.8-1.0 m layer 
1997 standard; electrolytic conductivity (EC) according to PN-ISO 11265 standard + ACI: 1997, hydrolytic acidity (Hh) according to PN-R04027:1997 standard, chloride content according to PN-ISO 9297: 1994 standard, organic carbon content according to 14235: 2003 standard, content of available nitrogen forms, according to PNR-04028:1997 standard and, content of available phosphorus, according to [Ostrowska et al. 1991].

\section{RESULTS AND DISCUSSION}

The determination of the physical properties (Table 1) constituted a very important stage of the research work. On the scarp, at the depth of $0-0.3$ $\mathrm{m}$, loose sand was found, and at the depth of $0.8-1.0 \mathrm{~m}$, the loamy sand was found. At the both depths studied, the dark-brown and the brownyellow color predominates. In the top level, the soil was characterized by a sallow smell, in the level with a deeper, organic-specific odor, characteristic of ammonia. By the road in the upper level "a" loose sands, loamy loams, loamy light and strong ones were found, while in the middle of the deeper "b" level, medium clay was found in a single. In the "a" level, the dark and brown colors prevailed, while in the deeper "b", the colors were lighter, yellow. At both depths, there was an earthy smell and in two samples at a depth of $0.8-1.0 \mathrm{~m}$, a slightly specific odor was observed.

Table 2 presents the results of the performed analyses of $\mathrm{pH}$ value, hydrolytic acidity, electrolytic conductivity (EC) and chloride content. On the scarp (2), a larger difference in $\mathrm{pH}$ between the levels "a" and "b" was observed. By the road (1) the $\mathrm{pH}$ value increased with depth. This increase was smaller than on the scarp (2), ranging from about 0.5 to $1.0 \mathrm{pH}$ value, which was caused by the presence of soil alkalizing substances at the depth above $1.0 \mathrm{~m}$ (Figure 5). In the samples taken on the scarp (2) a negative correlation was found between the $\mathrm{pH}$ value and the hydrolytic acidity (the higher the $\mathrm{pH}$ value, the lower the acidity). Therefore, the "a" level values were slightly higher than the "b" level. Along the road (1), the hydrolytic acidity in the upper level was characterized by an elevated value, typical for forest soils. It is clearly visible that the electrolytic conductivity (EC) on the scarp (2) is about 10 times higher in the "b" level compared to the "a" level, which indicates a significant amount of soluble salts in the examined soils [Karczewska 2012], affecting the degree of their degradation.

Table 1. Physical properties of soil taken from two layers along the road (1) and on a landfill site (2)

\begin{tabular}{|c|c|c|c|c|c|c|}
\hline \multirow{2}{*}{$\begin{array}{c}\text { No of } \\
\text { sample }\end{array}$} & \multicolumn{2}{|c|}{ Soil formation* } & \multicolumn{2}{|c|}{ Munsell soil color, HUE 10YR } & \multicolumn{2}{|c|}{ Scent (intensity) ${ }^{* *}$} \\
\hline & „a” & „b" & ,a" & ,b" & „a” & „b” \\
\hline$I(1)$ & $\mathrm{s}$ & $\mathrm{s}$ & dark grayish brown $4 / 2$ & yellow $8 / 6$ & earthly (3) & chemical (2) \\
\hline II (1) & $\mathrm{s}$ & $\mathrm{s}$ & dark brown $3 / 3$ & yellow $7 / 6$ & chemical (1) & earthly (1) \\
\hline III (1) & $\mathrm{s}$ & $\mathrm{s}$ & light brownish gray $6 / 2$ & brownish yellow $6 / 6$ & earthly (1) & earthly (1) \\
\hline IV (1) & $\mathrm{s}$ & $\mathrm{s}$ & brown $4 / 3$ & yellow $7 / 6$ & earthly (2) & earthly (2) \\
\hline V (1) & $\mathrm{s}$ & $\mathrm{s}$ & brown $4 / 3$ & brownish yellow $6 / 6$ & earthly (2) & earthly (1) \\
\hline VI (1) & $\mathrm{s}$ & $\mathrm{scl}$ & yellowish brown $5 / 4$ & yellow $7 / 6$ & earthly (3) & chemical (2) \\
\hline VII (1) & $\mathrm{sl}$ & Is & dark grayish brown $4 / 2$ & grayish brown $5 / 2$ & earthly (2) & earthly (1) \\
\hline VIII (1) & Is & $\mathrm{s}$ & dark grayish brown $4 / 2$ & grayish brown $5 / 2$ & earthly (2) & earthly (1) \\
\hline $\mathrm{IX}(1)$ & $\mathrm{s}$ & $\mathrm{s}$ & dark grayish brown $4 / 2$ & grayish brown $5 / 2$ & earthly (1) & earthly (1) \\
\hline$X(1)$ & Is & $\mathrm{s}$ & grayish brown $5 / 2$ & yellowish brown $5 / 6$ & earthly (1) & earthly (1) \\
\hline$I(2)$ & $\mathrm{s}$ & $\mathrm{s}$ & dark yellowish brown $4 / 6$ & dark brown $3 / 3$ & ammonia (1) & ammonia (3) \\
\hline II (2) & $\mathrm{s}$ & $\mathrm{s}$ & dark yellowish brown $4 / 4$ & very dark gray $3 / 1$ & chemical (2) & chemical (3) \\
\hline III (2) & $\mathrm{s}$ & $\mathrm{s}$ & dark yellowish brown $3 / 6$ & very dark gray $3 / 1$ & chemical (2) & chemical (3) \\
\hline IV (2) & $\mathrm{s}$ & $\mathrm{s}$ & yellowish brown $5 / 8$ & dark grayish brown $4 / 2$ & ammonia (2) & ammonia (3) \\
\hline$V(2)$ & $\mathrm{s}$ & $\mathrm{s}$ & yellowish brown $5 / 8$ & very dark gray $3 / 1$ & organic (1) & organic (3) \\
\hline VI (2) & $\mathrm{s}$ & $\mathrm{s}$ & yellowish brown $5 / 8$ & black $2 / 1$ & ammonia (2) & ammonia (3) \\
\hline VII (2) & $\mathrm{s}$ & $\mathrm{s}$ & brownish yellow $6 / 8$ & very dark brown $2 / 2$ & rotten (1) & rotten (3) \\
\hline VIII (2) & $\mathrm{s}$ & $\mathrm{s}$ & brownish yellow 6/8 & black $2 / 1$ & ammonia (2) & ammonia (3) \\
\hline IX (2) & $\mathrm{s}$ & $\mathrm{s}$ & yellowish brown $5 / 8$ & yellowish brown $5 / 4$ & organic (1) & organic (3) \\
\hline$X(2)$ & $\mathrm{s}$ & $\mathrm{s}$ & brownish yellow $6 / 6$ & very dark gray $3 / 1$ & ammonia (2) & ammonia (3) \\
\hline
\end{tabular}

*Soil formation: s - sand, sl - sandy loam, ls - loam sand, scl - sandy clay loam; **Intensity of scent: weak (1), medium (2), strong (3) 
Table 2. Comparison of $\mathrm{pH}$, hydrolytic acid, EC and chloride acid results for samples taken along a forest road (1) and on a landfill site (2)

\begin{tabular}{|c|c|c|c|c|c|c|c|c|}
\hline \multirow{3}{*}{$\begin{array}{c}\mathrm{Nr} \\
\text { odwiertu }\end{array}$} & \multirow{2}{*}{\multicolumn{2}{|c|}{$\frac{\mathrm{pH}}{1 \mathrm{M} \mathrm{KCl}}$}} & \multirow{2}{*}{\multicolumn{2}{|c|}{$\begin{array}{c}\mathrm{Hh} \\
{[\mathrm{cmol}(+) / \mathrm{kg} \text { d.m.] }}\end{array}$}} & \multirow{2}{*}{\multicolumn{2}{|c|}{$\mathrm{EC}[\mu \mathrm{S} / \mathrm{cm}]$}} & \multirow{2}{*}{\multicolumn{2}{|c|}{$\begin{array}{c}\text { Chloride } \\
\text { [mg/kg d.m.] }\end{array}$}} \\
\hline & & & & & & & & \\
\hline & ,a” & „b" & ,a" & „b" & ,a” & „b" & ,a" & ,b” \\
\hline I (1) & 5.91 & 6.89 & 2.60 & 1.00 & 96.5 & 188.9 & 404.0 & 804.6 \\
\hline II (1) & 7.31 & 6.90 & 0.60 & 0.80 & 247.6 & 338.6 & 203.0 & 361.6 \\
\hline III (1) & 5.05 & 4.86 & 3.80 & 1.40 & 356.5 & 472.2 & 302.6 & 401.8 \\
\hline IV (1) & 5.44 & 6.96 & 4.40 & 0.60 & 601.5 & 396.4 & 616.8 & 453.8 \\
\hline$V(1)$ & 6.8 & 6.97 & 2.00 & 3.80 & 413.5 & 409.1 & 50.9 & 402.7 \\
\hline VI (1) & 5.3 & 5.63 & 3.80 & 1.40 & 56.8 & 43.8 & 909.1 & 602.6 \\
\hline VII (1) & 5.65 & 5.97 & 4.00 & 1.40 & 152.0 & 226.4 & 508.0 & 501.2 \\
\hline VIII (1) & 7.05 & 6.99 & 2.00 & 0.80 & 764.5 & 330.3 & 506.8 & 402.2 \\
\hline IX (1) & 4.91 & 6.47 & 7.60 & 1.00 & 439.2 & 173.5 & 508.6 & 301.1 \\
\hline$X(1)$ & 4.9 & 5.62 & 6.40 & 1.60 & 159.6 & 426.5 & 805.4 & 1006.6 \\
\hline$I(2)$ & 5.39 & 7.92 & 3.80 & 0.40 & 125.3 & 1707.9 & 604.9 & 519.9 \\
\hline II (2) & 5.48 & 7.57 & 1.80 & 1.40 & 83.6 & 2091.0 & 251.0 & 656.4 \\
\hline III (2) & 6.75 & 7.61 & 2.00 & 2.20 & 141.1 & 2991.0 & 300.5 & 1856.0 \\
\hline IV (2) & 5.3 & 7.79 & 2.00 & 1.00 & 278.4 & 3330.0 & 252.1 & 1874.7 \\
\hline V (2) & 5.33 & 8.15 & 2.00 & 2.40 & 697.2 & 3487.0 & 620.0 & 2902.2 \\
\hline VI (2) & 6.02 & 7.37 & 2.20 & 1.40 & 81.0 & 3328.0 & 705.1 & 2345.5 \\
\hline VII (2) & 5.23 & 7.39 & 3.00 & 1.60 & 60.8 & 3025.0 & 704.7 & 2646.0 \\
\hline VIII (2) & 5.37 & 7.87 & 2.40 & 1.60 & 91.2 & 1739.2 & 327.4 & 651.3 \\
\hline IX (2) & 5.93 & 8.01 & 2.00 & 0.40 & 61.5 & 1543.5 & 403.0 & 829.0 \\
\hline$X(2)$ & 5.56 & 7.43 & 1.60 & 1.40 & 95.6 & 2533.0 & 802.0 & 2542.3 \\
\hline
\end{tabular}

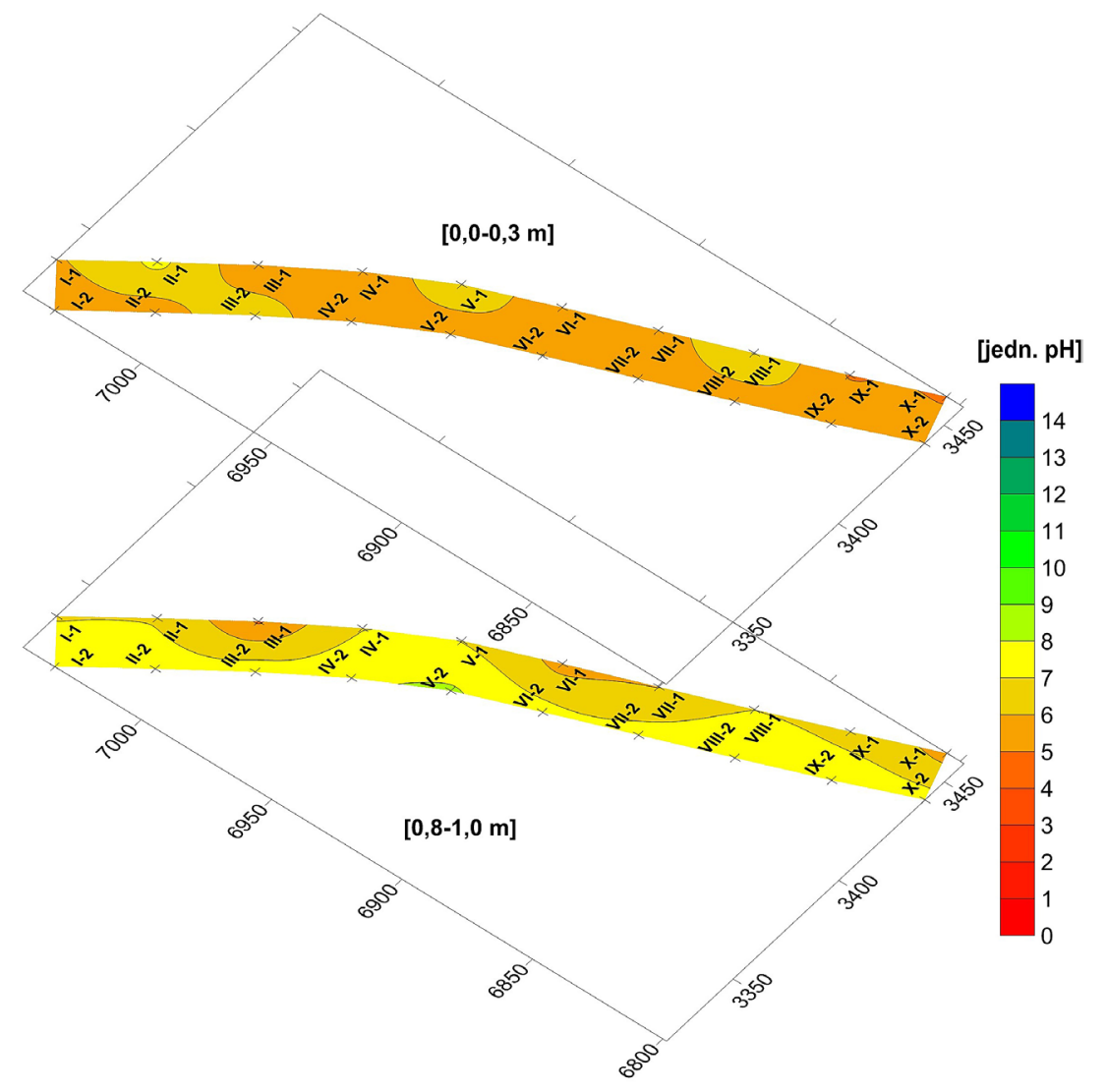

Figure 5. Simulation of the $\mathrm{pH}$ distribution between the individual wells along the forest road (1) and on the scarp of the landfill (2) 
The soil collected by the road (1) in which low values of EC were found in both levels (Figure 6) may constitute the reference sample. The chloride content is equally high and correlates with the value of EC. The highest content of chlorides was found in the samples taken from the scarp (2) in the deeper level "b", which may pose a potential threat to groundwater (Figure 7).

Table 3 summarizes the results of analysis involving the organic carbon content, absorbed phosphorus and nitrogen forms. The obtained results of the organic carbon content along the forest road (1) show the correct tendency, as they are higher in the "a" level $(0-0.3 \mathrm{~m})$. At this level, the accumulation and decomposition of organic matter, characteristic of natural processes, occurs [Zawadzki 1999; Bednarek et al. 2005]. In the case of the boreholes located on the scarp's landfill (2), the results of the organic carbon content increase with depth (Figure 8). Such a high content of organic matter is caused by leaching it from the waste. The content of available phosphates on the scarp (2) at the depth "b" (0.8-1.0 $\mathrm{m})$ reached very high values compared to the upper levels "a" on the scarp (2) and along the road (1) (Figure 9). This probably indicates a progres- sive decomposition of the substance, occurring in the mass of littering waste, which may pose a serious threat to the groundwater. The high values of phosphates analyzed correlated with the perceptible specific smell of organic compounds.

The nitrate nitrogen content on the scarp (2) was significantly higher than on the road (1), especially at the "b" level $(0.8-1.0 \mathrm{~m})$ (Figure 10). The highest content of ammonium nitrogen was found in the border wells. The content of ammonium nitrogen on the scarp (2) was very high and in the sample III (2) in the level "b" it amounted to $1917.91 \mathrm{mg} / \mathrm{kg}$ d.m. The difference between the levels "a" and "b" was very clear, in each borehole a higher content of the examined feature was noted at a depth of $0.8-1.0 \mathrm{~m}$ (Figure 11). The high analyzed ammonium nitrogen content correlated with the perceived specific smell of ammonia.

Summing up, the vertical and horizontal migration of pollutants from the landfill may become a big threat to the soil and water environment. The landfill is also a potential geotechnical hazard because it is a dynamically changing object that can change stability, create caverns and landslides.

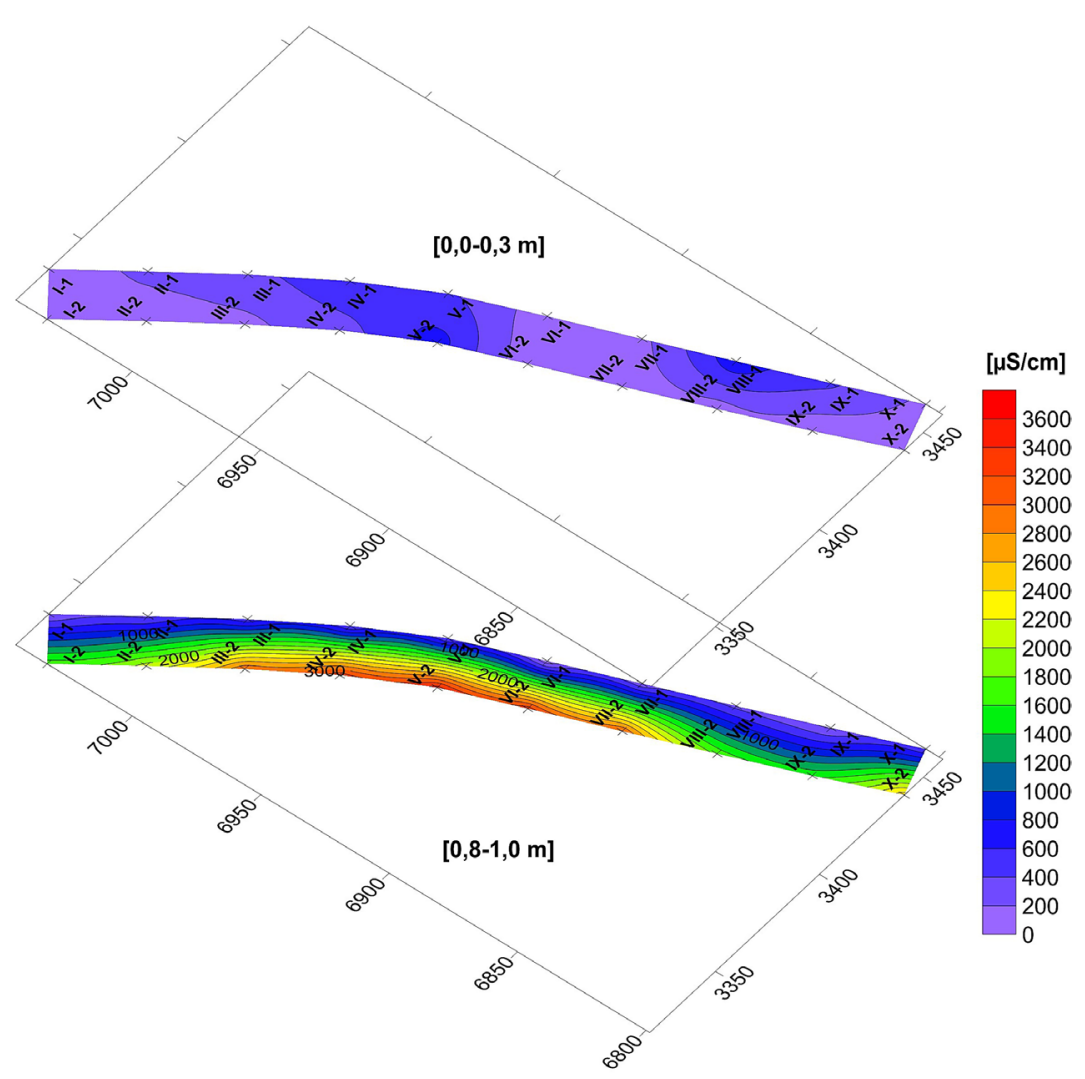

Figure 6. Simulation of the electrolytic conductivity (EC) distribution between individual wells along the forest road (1) and on the scarp of the landfill (2) 


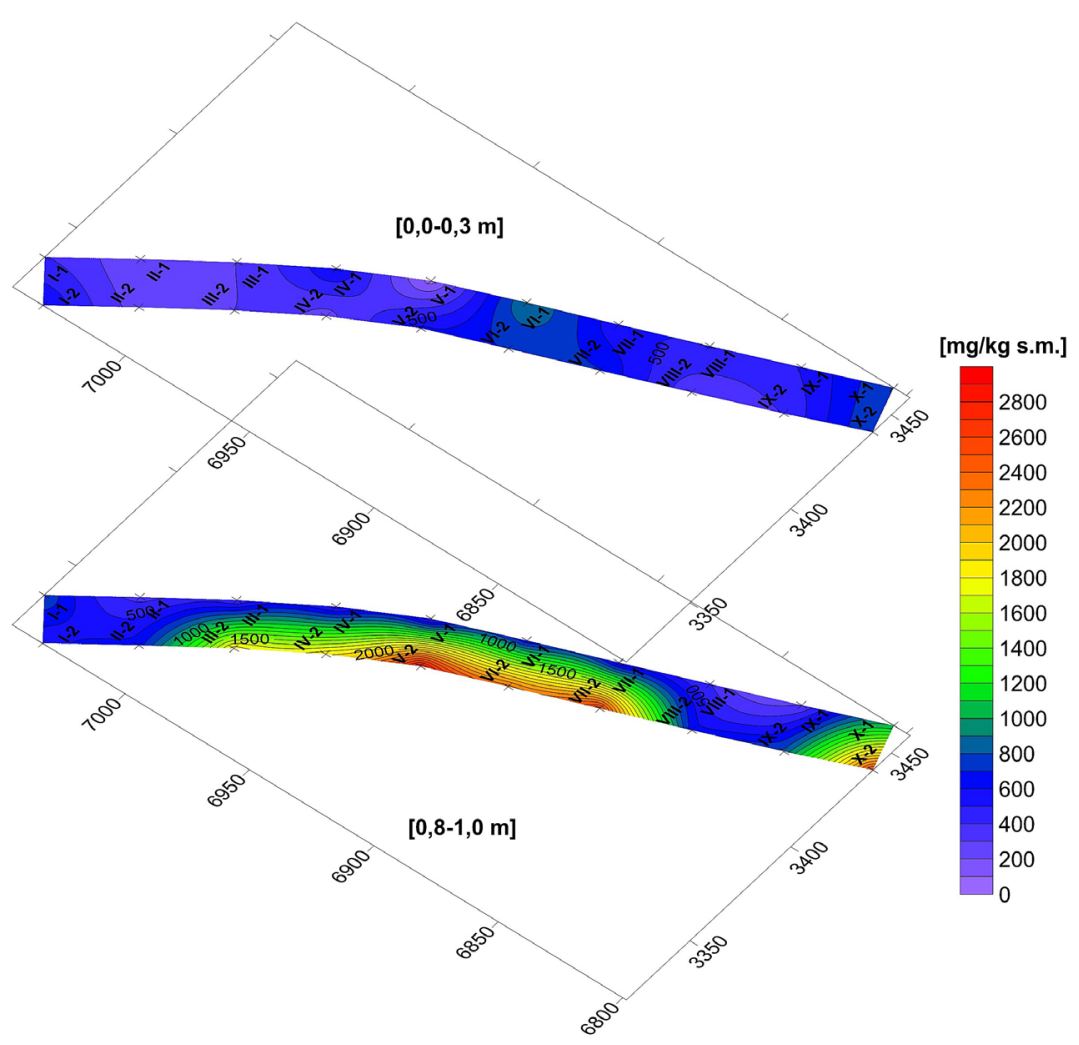

Figure 7. Simulation of the distribution of chloride content between individual wells along the forest road (1) and on the scarp of the landfill (2)

Table 3. Content of carbon, available phosphorus and nitrogen forms in the soil samples taken along the forest road (1) and on the scarp of the landfill (2)

\begin{tabular}{|c|c|c|c|c|c|c|c|c|}
\hline \multirow{3}{*}{$\begin{array}{l}\text { No of } \\
\text { sample }\end{array}$} & \multirow{2}{*}{\multicolumn{2}{|c|}{$\begin{array}{c}\text { Organic carbon } \\
{[\%]}\end{array}$}} & \multirow{2}{*}{\multicolumn{2}{|c|}{$\begin{array}{l}\text { Available phosphorus } \\
{\left[\mathrm{mgP}_{2} \mathrm{O}_{5} / \mathrm{kg} \mathrm{d} \text { d.m.] }\right.}\end{array}$}} & \multicolumn{4}{|c|}{ Nitrogen [mg/kg d.m.] } \\
\hline & & & & & \multicolumn{2}{|c|}{ ammonia } & \multicolumn{2}{|c|}{ nitrate } \\
\hline & „a" & „b” & „a” & „b" & ,a” & „b” & ,a" & „b” \\
\hline I (1) & 1.724 & 0.890 & 24.2 & 120.7 & 404.03 & 402.32 & 85.86 & 70.41 \\
\hline II (1) & 0.836 & 0.119 & 162.4 & 41.3 & 274.04 & 69.74 & 5.07 & 2.07 \\
\hline III (1) & 1.514 & 0.033 & 242.1 & 32.1 & 58.00 & 57.76 & 20.17 & 1.00 \\
\hline IV (1) & 3.940 & 0.477 & 205.6 & 40.3 & 277.55 & 68.07 & 10.28 & 2.02 \\
\hline$V(1)$ & 1.542 & 0.349 & 407.2 & 40.3 & 274.84 & 171.14 & 2.04 & 5.03 \\
\hline VI (1) & 1.602 & 0.596 & 202.0 & 24.1 & 22.73 & 20.09 & 5.05 & 1.51 \\
\hline VII (1) & 1.546 & 0.356 & 203.2 & 24.1 & 33.02 & 92.72 & 3.05 & 18.04 \\
\hline VIII (1) & 1.849 & 0.356 & 186.5 & 40.2 & 50.68 & 25.14 & 65.88 & 30.17 \\
\hline$I X(1)$ & 2.955 & 0.238 & 81.4 & 20.1 & 50.86 & 27.61 & 27.47 & 15.06 \\
\hline$X(1)$ & 1.723 & 1.945 & 80.5 & 32.2 & 90.61 & 40.26 & 5.54 & 110.72 \\
\hline$I(2)$ & 2.310 & 1.419 & 282.3 & 2495.7 & 90.73 & 779.91 & 30.24 & 129.99 \\
\hline II (2) & 0.179 & 1.155 & 241.0 & 3675.6 & 77.81 & 1772.16 & 50.20 & 78.76 \\
\hline III (2) & 0.497 & 7.671 & 240.4 & 2969.7 & 57.60 & 1917.91 & 5.01 & 61.87 \\
\hline IV (2) & 0.716 & 3.280 & 201.7 & 2707.8 & 118.48 & 1405.99 & 5.04 & 26.04 \\
\hline$V(2)$ & 2.547 & 3.597 & 248.0 & 3009.7 & 320.35 & 994.27 & 7.23 & 2.15 \\
\hline VI (2) & 1.135 & 5.547 & 137.0 & 2855.4 & 553.97 & 1682.64 & 5.04 & 20.40 \\
\hline VII (2) & 1.479 & 2.187 & 88.6 & 2116.8 & 193.79 & 1068.58 & 4.03 & 20.35 \\
\hline VIII (2) & 0.534 & 4.178 & 131.0 & 2822.2 & 62.76 & 705.55 & 2.18 & 3.80 \\
\hline IX (2) & 0.834 & 1.769 & 120.9 & 2486.9 & 37.78 & 217.60 & 6.04 & 1.04 \\
\hline$X(2)$ & 1.123 & 3.396 & 120.3 & 1694.8 & 37.59 & 635.57 & 7.02 & 158.89 \\
\hline
\end{tabular}




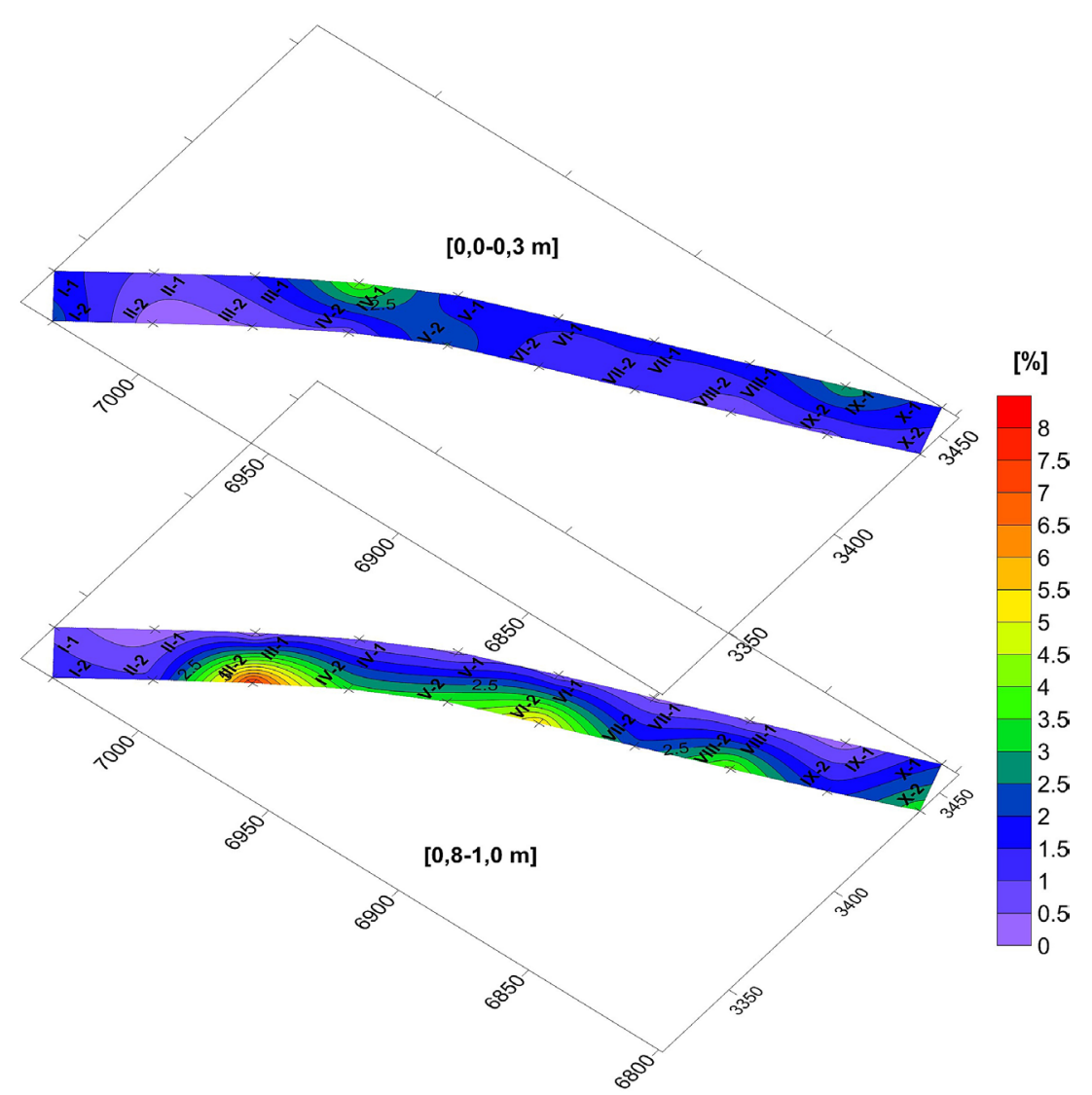

Figure 8. Simulation of the distribution of organic carbon content between individual wells along the forest road (1) and on the scarp of the landfill (2)

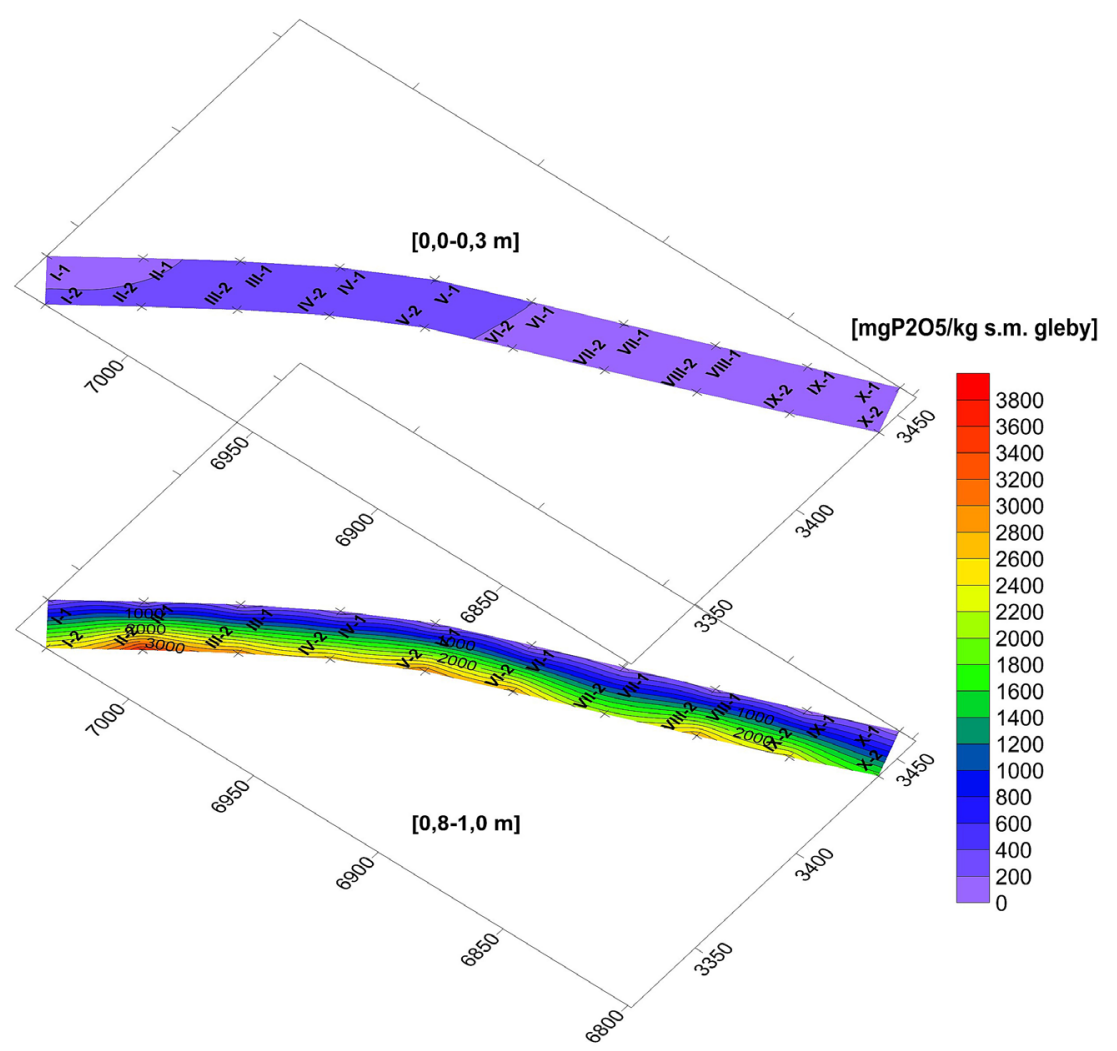

Figure 9. Simulation of the distribution of organic carbon content between individual wells along the forest road (1) and on the scarp of the landfill (2) 


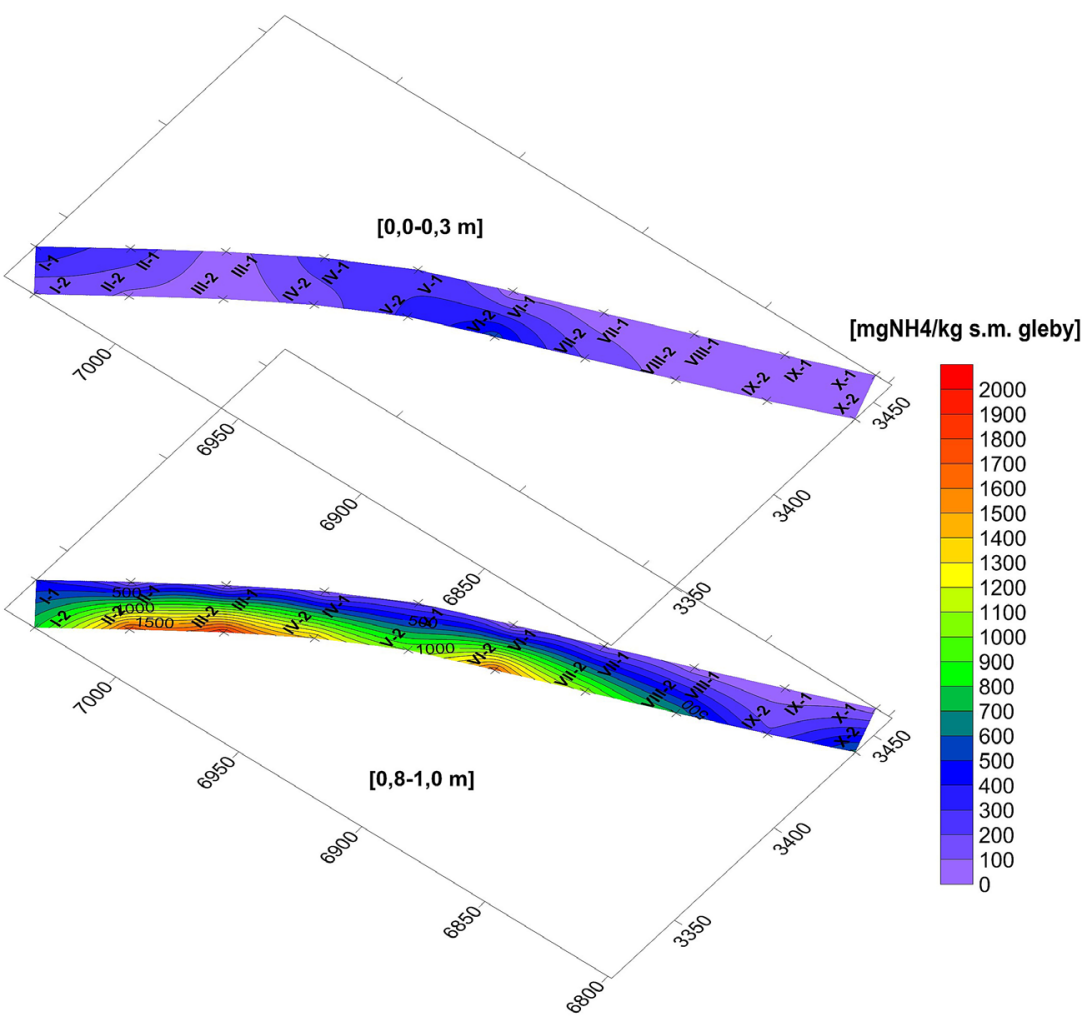

Figure 10. Simulation of the distribution of nitrate nitrogen between individual wells along the forest road (1) and on the scarp of the landfill (2)

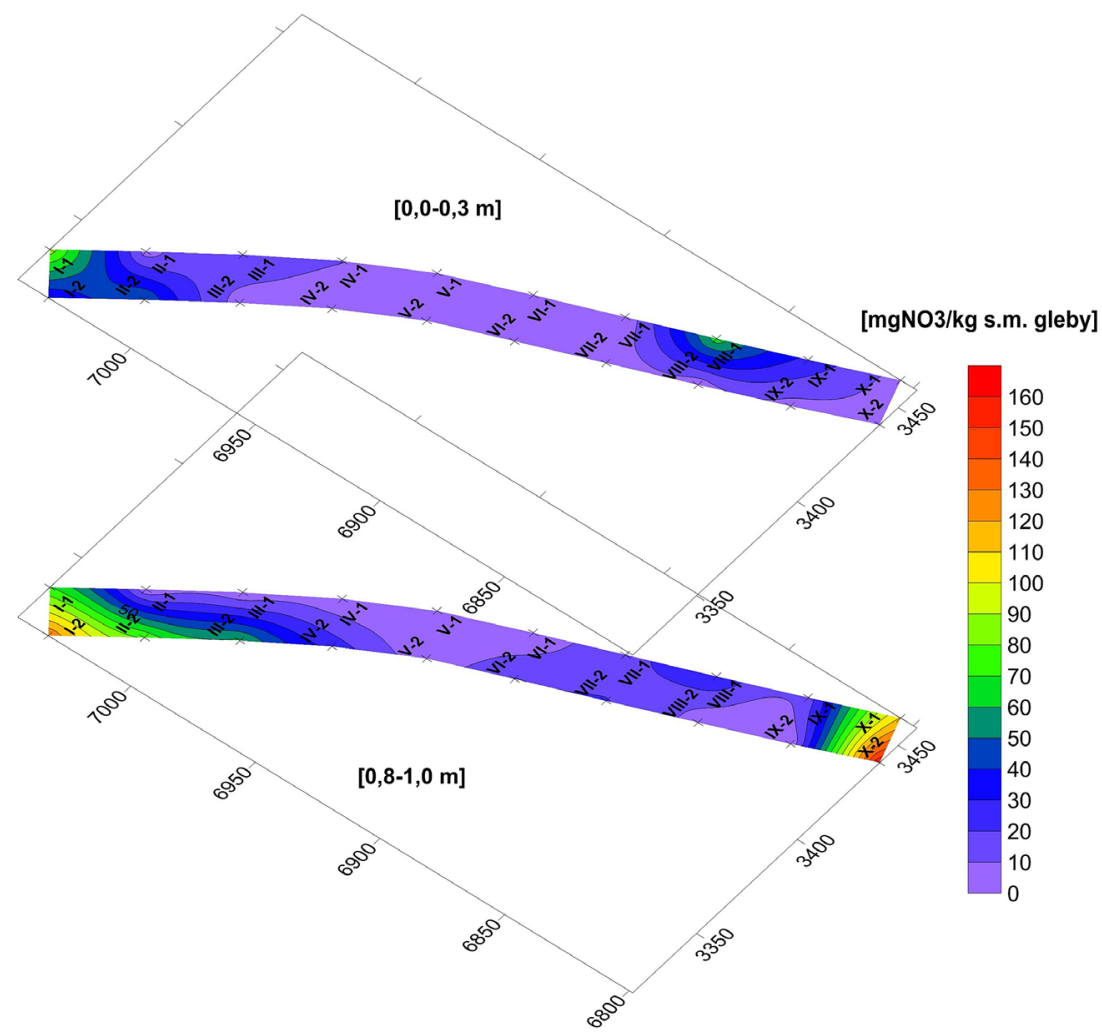

Figure 11. Simulation of the distribution of ammonium nitrogen content between individual wells along the forest road (1) and on the scarp of the landfill (2) 


\section{CONCLUSIONS}

1. In the western part of the former landfill site, the area under the supervision of the Warsaw Forests, an increased content of EC, chlorides, ammonium and nitrate nitrogen and assimilable phosphorus in the layer of $0.8-1.0 \mathrm{~m}$ was observed. There was also a close relationship between the perceptible smell of ammonia, and high content of ammonium nitrogen.

2. An increased content of organic carbon and higher $\mathrm{pH}$ values were found in relation to the soils surrounding the landfill (acidic soils).

3. High content of the above-mentioned properties testifies to the anthropogenic pollution. The most likely cause of contamination of the investigated soils involves the leachates from the landfill, which pose a risk of groundwater contamination.

4. The samples taken on the scarp of the repository, especially from the depth of $0.8-1.0 \mathrm{~m}$, were characterized by much higher values of the tested properties than the samples taken at a distance of about 5-10 $\mathrm{m}$ from the scarp.

5. The samples taken from the deeper levels on the scarp of the landfill were characterized by a sharp specific organic smell, which indicates the migration of leachate through the permeable layers deep into the ground.

6. The landfill site is to a large extent chemically degraded and constitutes a potential hazard to the groundwater, which should be tested and monitored.

\section{REFERENCES}

1. Bednarek R., Dziadowiec H., Pokojska U., Prusinkiewicz Z. 2005. Ecological and soil science research (in Polish). PWN, Warszawa.

2. Grygolczuk-Patersons E., Wiater J. 2012. Influence of municipal landfill site on the ground water quality (in Polish). Inżynieria Ekologiczna, No 31.

3. Karczewska A. 2012. Soil protection and reclamation of degraded areas (in Polish). Wydawnictwo Uniwersytetu Przyrodniczego we Wrocławiu,
Wrocław.

4. Koda E., Koper M. 2009. Assesment of reclamation efficiency of old municipal landfills (in Polish). VIII Międzynarodowe Forum Gospodarki Odpadami „Integrated waste management”. Poznań.

5. Marcinkowski (Ed.) 2009. Comprehensive waste management management (in Polish). Polskie Zrzeszenia Inżynierów i Techników Sanitarnych Oddział Wielkopolski, Poznań.

6. Mizera A. 2007. Soil - mechanisms of its degradation and methods of reclamation (in Polish). Green World - Ochrona Środowiska i Ekologia.

7. Ostrowska A., Gawliński S., Szczubiałka Z. 1991. Methods of analysis and assessment of soil and plant properties (in Polish), Katalog, Instytut Ochrony Środowiska, Warszawa.

8. PN-ISO 11464:1999 - Soil quality - Pretreatment of samples for physico-chemical analyses (in Polish).

9. PN-ISO 10390:1997 - Soil quality - Determination of $\mathrm{pH}$ (in Polish).

10. PN-ISO 11265 + ACI:1997 - Soil quality - Determination of the specific electrical conductivity (in Polish).

11. PN-ISO 9297:1994 - Water quality - Determination of chloride - Silver nitrate titration with chromate indicator (Mohr's method) (in Polish).

12. PN-ISO 14235:2003 - Soil quality - Determination of organic carbon by sulfochromic oxidation (in Polish).

13. PN-R-04027:1997 - Agrochemical soil analysis - Determination of hydrolytic acidity in mineral soils (in Polish).

14. PN-R-04028:1997 - Agrochemical soil analysis - Determination of nitrate and ammonium ions in the mineral soils (in Polish).

15. Siuta J. 1995. Soil - diagnosis of condition and threat (in Polish). Institute of Environmental Protection, Warszawa.

16. Tabor A., Generowicz A., Korzeniowska - Rejmer E., Sacharczuk J., Truś S. 2008. Waste management and land protection, Vol. III (in Polish). Centrum szkolenia i organizacji systemów jakości Politechniki Krakowskiej im. Tadeusza Kościuszki.

17. The Waste Act of 14 December 2012 (Dz.U. 2013 poz. 21, z późn. zm.) (in Polish).

18. Zawadzki S. 1999. Soil Science (in Polish). Państwowe Wydawnictwo Rolnicze i Leśne, Warszawa. 